\title{
Intervention of Echinochloa crusgalli on Growth Morphology of Rice
}

\author{
S. Anandha Krishnaveni ${ }^{*}$ and K. Prasanna ${ }^{2}$ \\ ${ }^{1}$ Anbil Dharmalingam Agricultural College and Research Institute, Trichy, India \\ ${ }^{2}$ Agricultural College \& Research Institute, Killikulam, Tamil Nadu, India
}

*Corresponding author:

\section{Keywords}

Barnyard Grass,

Weed density,

Growth

Morphology, Rice

Article Info

Accepted:

26 December 2018

Available Online:

10 January 2019
A B S T R A C T

An experiment was conducted in the experimental farm of Anbil Dharmalingam Agricultural College and Research Institute, Trichy to study the effect of barnyard grass (Echinochloa crusgalli) density on growth morphology and yield response of rice (Oryza sativa L.) during the period of February to May 2018. The experiment was laid out in Randomized block design with four replications and five treatments. The pots were filled with field soil. Based on the area calculation in each pot four rice seedlings were transplanted along with different weed densities. The growth parameters viz., plant height, number of tillers and LAI were recorded. The results revealed that the growth morphology of rice was reduced significantly when compared to weed free condition, as there was no competition from the weed species. The growth morphology of the rice plant was reduced gradually from weed free environment to plant with higher densities of barnyard grass. Also found that no growth was seen after vegetative stage of rice. This is because the banyard grass suppresses the growth of rice crop. Hence it is very important to control barnyard grass (Echinochloa crus-galli.) density for the better growth and yield of rice

\section{Introduction}

Rice is one of the most important staple foods for more than half of the world's population and influences the livelihoods and economies of several billion people. In Asia, more than $80 \%$ of the people live on rice and their primary food security is entirely dependent on the volume of rice produced in this part of the world. Weeds are at present the major biotic constraint to increase rice production worldwide. About $33 \%$ losses are caused due to weeds alone. The yield losses due to uncontrolled weed growth in lowland and upland rice ranged from $12-81 \%$. Normally, the loss in rice yield ranges between 15-20\% yet in severe cases the yield losses can be more than $50 \%$ depending upon the species and intensity of weeds.

Agriculture is a fight against weeds. Weeds are always present on every hectare of crop in the world. Among the weed species Echinochloa crusgalli (banyard grass) and Echinochloa colonum (jungle rice) are predominant grass weeds in rice (Ali and Shankaran, 1984; Ali, 1985). Echinochloa crusgalli is a tufted annual, tall and often 
weedy; culms erect to decumbent, 0.8 to $1.5 \mathrm{~m}$ tall, rather thick, branching at base. Leaves flat, glabrous, elongate $30-50 \mathrm{~cm}$ long, $1-2 \mathrm{~cm}$ broad, scabrous, slightly thickened at the margin, ligules absent, sheath smooth, lower ones often reddish, panicle 8-30 cm long, green or purple, exerted somewhat nodding densely branched, the branches to $5 \mathrm{~cm}$ long, erect or ascending sessile.

In comparison with rice, Echinochloa crusgalli emerges more quickly than rice and has a lower temperature threshold than that for rice. Weed control is an essential and important component of rice production. The rice yields will also dropped due to weed density. Therefore, it is important to study the extent of yield loss due to different density of, Echinochloa crusgalli in rice. Keeping this in view, a study was conducted to find out the effect of different densities of the weeds on growth morphology and yield of rice.

\section{Materials and Methods}

An experiment was conducted in the farm of Anbil Dharmalingam Agricultural College and Research Institute, Trichy to study the effect of Echinochloa crusgalli (barnyard grass) density on growth morphology and yield of rice (Oryza sativa $L$ ). The experiment was conducted as a pot experiment in the field during the period of February to May 2018 in Randomized Block Design (RBD) with four replications and comprising five treatments as follows:

$\mathrm{T}_{0}$ - Control or weed free condition [E.crusgalli $-0 /$ pot]

$\mathrm{T}_{1}$ - One weed plant per pot [E.crusgalli $1 / \mathrm{pot}$ ] $\mathrm{T}_{2}$ - Two weed plants per pot [E.crusgalli 2 / pot] $\mathrm{T}_{3}$-Three weed plants per pot [E.crusgalli $3 /$ pot]

$\mathrm{T}_{4}$ - Four weed plants per pot [E.crusgalli 4 / pot]

Rice and weed seeds were put in cloth bag and kept them under tap water for 24 hours for sprouting. The sprouted seeds were sown in the prepared seed beds. The twenty five days old seedlings were transplanted in the pot on. The spacing adopted is $15 \times 10 \mathrm{~cm}$ in each plant. The diameter of the pot was $28 \mathrm{~cm}$ and the area of the pot was $0.0625 \mathrm{~m}^{2}$. The pots were filled with field soil. Hence in each pot 4 rice seedlings were transplanted. The pots were placed on the open field. An amount of FYM was added to each pot before transplanting. Urea @1.3g is top dressed on each pot. As per the treatments the Echinochloa crus-galli seedlings were transplanted on the centre of the pot and the space between the rice seedlings. Control or monoculture of rice seedlings was also maintained for the comparison of the weed density effects. The observations were taken regularly for the growth morphology of the rice. Other weed plant species were removed or uprooted time to time to avoid extra competition.

The biometric observations on growth morphological characters like Plant height, leaf length, leaf breadth, leaf area per plant, number of tillers per hill, leaf area index(LAI), plant were taken at 15 and 30 DAT. The collected data's were analyzed statistically. Correlation between weed density and rice growth was studied.

\section{Results and Discussion}

An experiment was conducted with an objective to study the effect of Echinochloa crusgalli density of rice. The results were statically analysed and the data were presented in Table 1. The results obtained from the study showed that the growth morphology of the rice plant was reduced gradually from the weed free environment to the pot with 4 nos of barnyard grass. Also no growth was seen after the vegetative stage. This is because the presence of Echinochloa crusgalli completely suppresses the growth of the rice crop. These 
similar findings were observed by Fazlul et al., (2003).

\section{Plant height}

The plant height was significantly influenced by density of Echinochloa crusgalli. The highest plant height was recorded in the weed free condition and was found to be decreased gradually as the intensity of weed in the pot increased (Table 1 and Fig. 1). The minimum plant height was recorded in $\mathrm{T}_{5}$ (Echinochloa crusgalli 4 no's /plot).

Table.1 Effect of Echinochloa crusgalli density on rice growth morphology

\begin{tabular}{|l|c|c|c|c|c|c|}
\hline \multirow{2}{*}{\multicolumn{1}{|c|}{ Details }} & \multicolumn{2}{|c|}{$\begin{array}{c}\text { Plant height } \\
(\mathbf{c m})\end{array}$} & \multicolumn{2}{c|}{$\begin{array}{c}\text { Number of tillers } \\
\text { per hill }\end{array}$} & \multicolumn{2}{c|}{$\begin{array}{c}\text { Leaf Area Index } \\
\text { (LAI) }\end{array}$} \\
\cline { 2 - 8 } & 15 DAT & 30 DAT & 15 DAT & 30 DAT & 15 DAT & 30 DAT \\
\hline Weed free condition & 25.55 & 39.22 & 4.56 & 9.31 & 0.38 & 1.67 \\
\hline $\begin{array}{l}\text { Echinochloacrusgalli @ } \\
\text { 1/pot }\end{array}$ & 22.99 & 29.36 & 4.13 & 7.31 & 0.26 & 1.14 \\
\hline $\begin{array}{l}\text { Echinochloacrusgalli @ } \\
\text { 2/pot }\end{array}$ & 20.95 & 27.70 & 3.75 & 6.75 & 0.20 & 0.85 \\
\hline $\begin{array}{l}\text { Echinochloacrusgalli @ } \\
\text { 3/pot }\end{array}$ & 18.94 & 26.59 & 3.31 & 5.81 & 0.14 & 0.70 \\
\hline $\begin{array}{l}\text { Echinochloacrusgalli @ } \\
\text { 4/pot }\end{array}$ & 17.64 & 24.14 & 3.13 & 5.00 & 0.11 & 0.60 \\
\hline SEd & & & & & & \\
\hline CD(P=0.05) & 0.17 & 0.87 & 0.13 & 0.19 & 0.01 & 0.02 \\
\hline
\end{tabular}

Fig.1

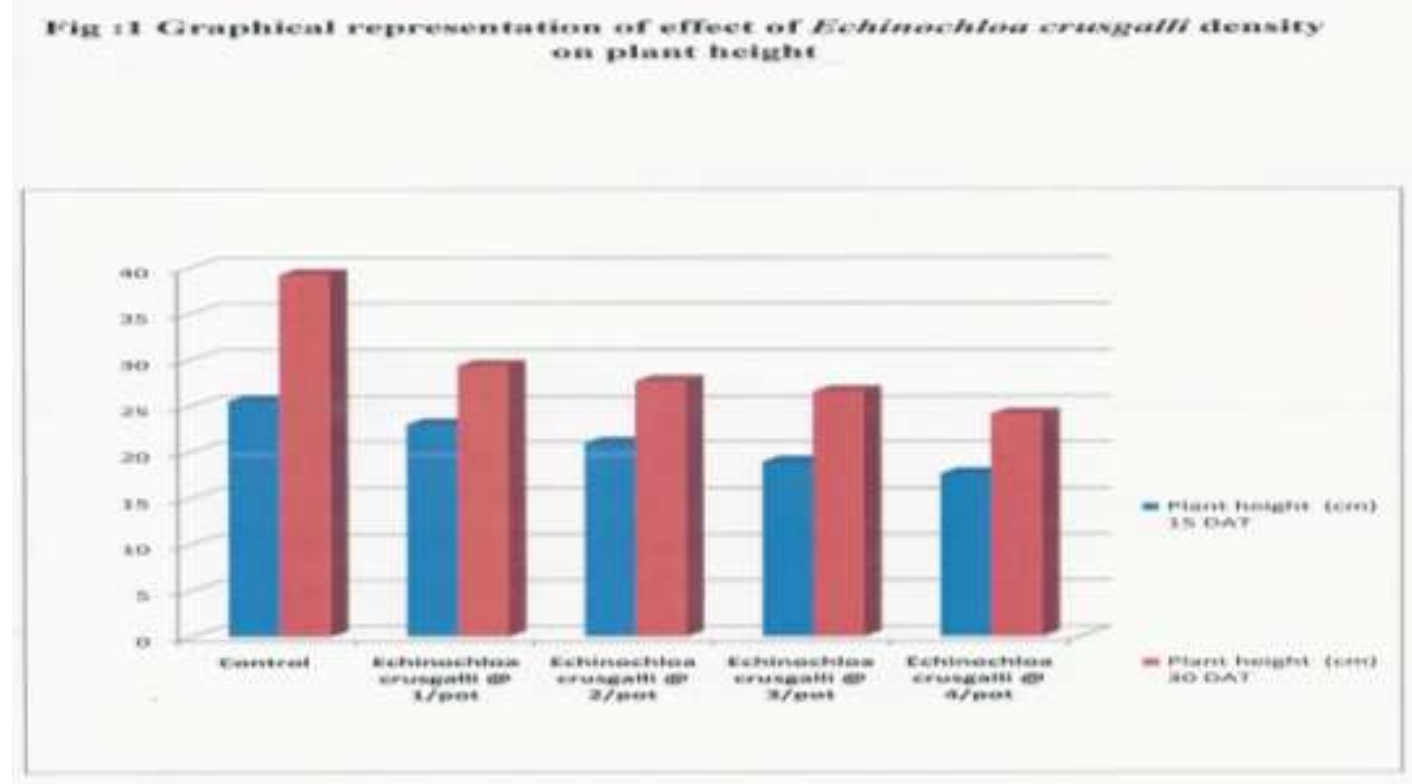


Fig.2

Fig $: 2$ Graphical representation of effect of Echinochloa crusgalli density on No. of tillers

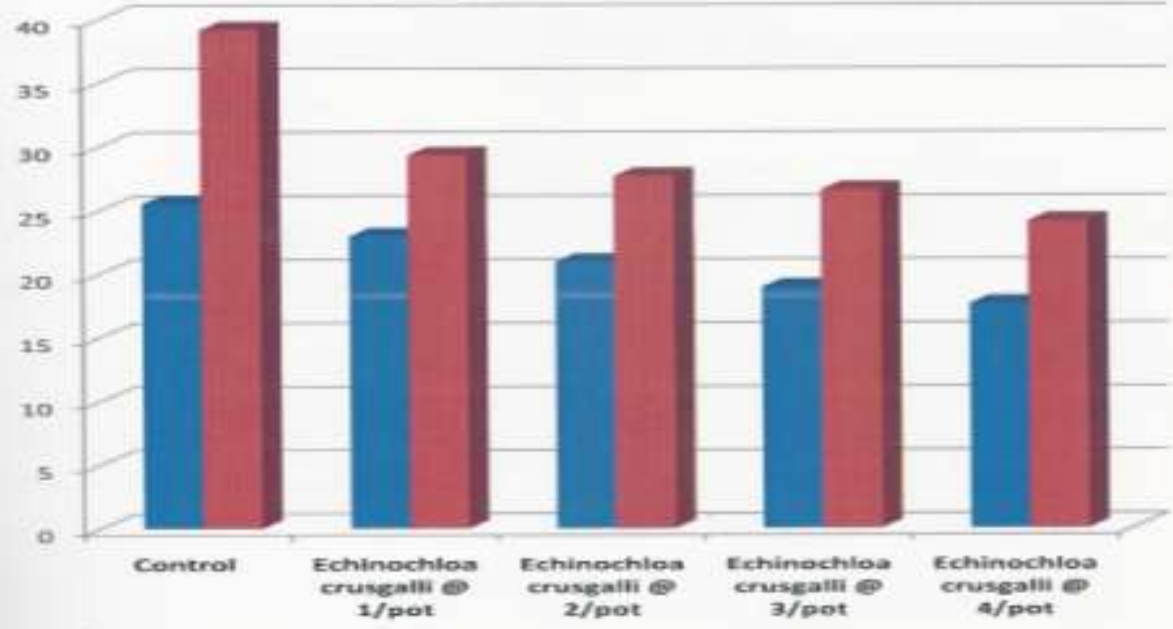

Fig.3

Fig a3 Graphieat representation of efreet of Echinochlou crusgall density on Leaf Area Index

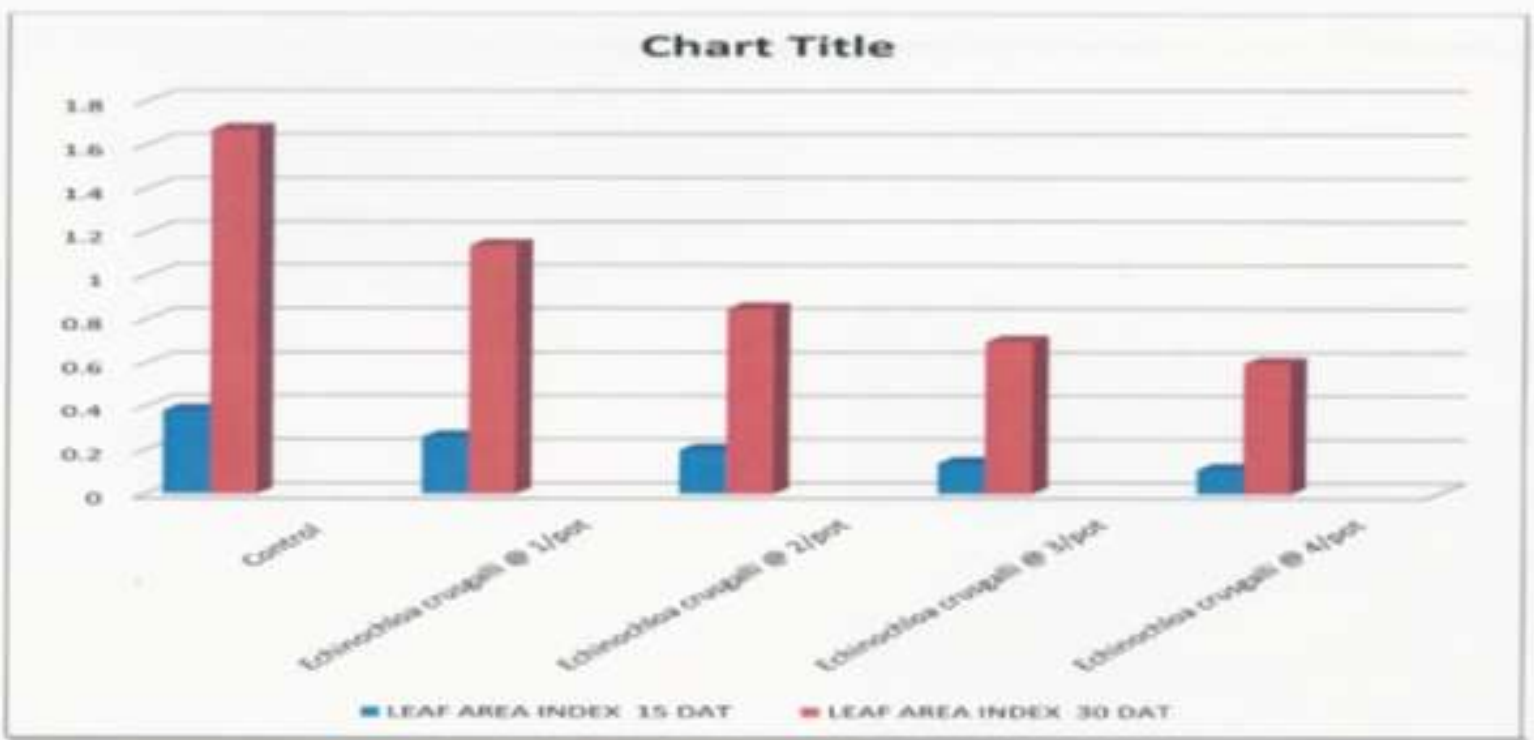


The maximum height recorded was $29.22 \mathrm{~cm}$ at $15 \mathrm{DAT}$ and $39.22 \mathrm{~cm}$ at $30 \mathrm{DAT}$ and the minimum plant height recorded was $17.64 \mathrm{~cm}$ at 15 DAT and $24.14 \mathrm{~cm}$ at 30 DAT. The reduction in the plant height was mainly due to the severe competition provided by the barnyard grass. Similar study was conducted by Tachibana, M. Watanabe, H., 1998.

\section{Number of tillers}

As like the plant height, there was a significant difference in the treatments. The weed density has similar effects on the number of tillers per plant. From the observations recorded, the maximum number of tillers (4.56 and 9.31 at 15 and 30 DAT respectively) was recorded in the weed free environment and it was found to be gradually decreased as the density of the weed species increased in the pot (Table 1 and Fig. 2). This clearly indicates that the reduction in the number of tillers was due to the competition effect exhibited by the barnyard grass (Tachibana et al., 1999). The findings are also in agreement with that of Azmi (1988)

\section{Leaf area index}

The observations on leaf length and leaf breadth at both 15 DAT and 30 DAT were recorded. From the above observations, the leaf area index was derived from the following formula

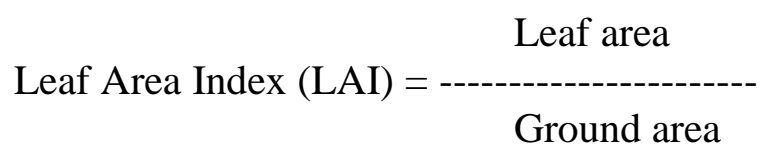

It was found that there was significant difference among the treatments (Table 1 and Fig. 3). The highest LAI was recorded in the weed free environment ( 0.38 and 1.67 at 15 DAT and 30 DAT respectively) and as like the above two parameters the minimum LAI was recorded in the treatment with $\mathrm{T}_{5}$.
In conclusion, the effect of Echinochloa crusgalli on the rice growth was studied. By analyzing the study, the growth of the rice crop was reduced significantly when compared to weed free condition, as there was no competition from the weed species. Also the height of the plant was also varied from weed free condition to other treatments. Lesser number of tillers was produced by rice plants under the influence of barnyard grass due to competition.

The results obtained from the study showed that the growth morphology of the rice plant was reduced gradually from weed free environment to plant with higher densities of barnyard grass. Also no growth was seen after vegetative stage. This is because the barnyard grass suppresses the growth of rice crop. Hence it is very important to control barnyard grass (Echinochloa crus-galli.) density for the better growth and yield of rice. It is worthwhile to apply weed management practices before the establishment of barnyard grass.

\section{References}

Ali, M.A. and S. Sankaran, 1984. Crop weed competition in direct seeded lowland and upland bunded rice. Ind. J. Weed Sci., 19: 90-96.

Ali, M.A., 1985. Crop-weed competition. Proceedings of the Updated Abstracts of Papers of Annual Conference, (UAPAC'85), Indian Society of Weed Science, pp: 78-78.

Azmi, M., 1988. Weed competition in rice production. Proceedings of the National Seminar and Workshop on Rice Field Weed Management, (NSWRFWM'88), Penang, Malaysia, pp: 5-5.

Md. Fazlul Islam, S.M. Rezaul Karim, S.M.A. Haque, Md. Sirajul Islam and Md. Sirajul Islam, 2003. Effect of Population Density of Echinochloa 
crusgalli and Echinochloa colonum on Rice. Journal of Agronomy, 2: 120-125. Tachibana, M. and Watanabe, $H$. 1998.Growth of barnyard-grass emerging at different periods in the paddy field with different rice plant types. J. Weed Sci. Tech. 43 (Extra issue): $54-55$.

Tachibana, M., Watanabe, H., Uchino, A. and Kohara, H. 1999. Analysis of rice plant types at different growing periods in relation to the suppression of the barnyardgrass growth. J. Weed Sci. Tech. 44 (Extra issue): 200-201.

\section{How to cite this article:}

Anandha Krishnaveni, S. and Prasanna, K. 2019. Intervention of Echinochloa crusgalli on Growth Morphology of Rice. Int.J.Curr.Microbiol.App.Sci. 8(01): 3044-3049. doi: https://doi.org/10.20546/ijcmas.2019.801.324 